\title{
11 \\ Time in Portuguese saudade and other words of longing
}

\author{
Zuzanna Bułat Silva
}

\section{Introduction}

The basic aim of this article is to see how the category of TIME relates to the domain of EMOTIONs. I believe that the dimension of TIME is important while defining emotion concepts and that the recognition of this fact can have profound consequences for cross-cultural psychology. ${ }^{1}$ Drawing on some Natural Semantic Metalanguage (NSM) explications of emotions ${ }^{2}$ referring to 'pain caused by distance' in different languages, I am going to show the differences between various cultural conceptualisations of that 'intersection' of emotional spectrum. Comparing the Portuguese word saudade, roughly 'longing', with its Polish (tęsknota), Spanish (morriña), and Chinese (chou) counterparts, I am going to look at how the domain of TIME is captured in their meaning and how TIME relates to the intensity of emotions described by these terms. To be able to express myself from a culturally neutral perspective, I will rely here on the NSM approach (Wierzbicka 1996; Goddard and Wierzbicka 2002). Thanks to NSM,

1 The previous versions of this article were presented at the STALDAC conference, held at the University of Cambridge, UK, in April 2010 and at the talk given at the School of Language Studies, ANU, Canberra, in August 2013.

2 When I refer to emotions in this article, in most cases I mean 'emotion concepts embedded in words'. 
we are able, as Wierzbicka (2009: 4) notes, to 'explore human emotions from a universal point of view, independent of any particular languages and cultures'.

The present article will be organised as follows. First, in section 2, the NSM primes referring to TIME will be examined. Then, in section 3 different ways in which emotions may relate to TIME will be discussed. Section 4 will consist of the presentation of a key Portuguese emotion, saudade, together with its metalinguistic explication. And finally, in section 5, the explication of saudade will be contrasted with the explications of tęsknota, morriña and chou in order to show the different role TIME plays in each of these emotions.

\section{Semantic primes referring to the domain of TIME}

NSM is a theory of semantic analysis that has been developed over the period of more than 40 years. There are eight TIME primes in the most recent version of NSM: WHEN $\sim$ TIME, ${ }^{3}$ NOW, BEFORE, AFTER, A LONG TIME, A SHORT TIME, FOR SOME TIME and MOMENT. As with all the NSM primes, it is assumed that they exist in all languages in the world. Interestingly, in the earliest versions of NSM (Wierzbicka 1972), there were no TIME primes at all; temporal phenomena were defined via 'worlds becoming worlds' (Goddard 1998: 325).

Basic TIME primes proposed in Goddard and Wierzbicka (1994) were WHEN, BEFORE and AFTER. The authors argued that in every language one may ask simple questions, such as: 'When did it happen?' or 'When will you do it?', and also 'This someone died before this other someone' or 'This other someone died after this someone' (see Wierzbicka 1996: 57). Thanks to the categorical element WHEN $\sim$ TIME, it is easy to explicate different time adverbs. Then can be explained as 'at that time'; often - 'at many times'; always - 'at all times'; sometimes_-'at some times'; and ago-'some time before'. WHEN -TIME can be used with all the predicates as a 'temporal adjunct', as in 'at that time you did something bad' or 'some time before these people were doing something else' (Wierzbicka 1996: 132; Goddard

3 WHEN and TIME are two English allolexes (contextual variants) of the same prime. 
and Wierzbicka 2002: 66). ${ }^{4}$ These temporal adjuncts are best identified with reference to the prime Now, introduced in 1996; in other words, if one can substitute the temporal phrase with Now (or at this time), it is well-formed (Goddard and Wierzbicka 2002: 67).

As for AFTER and BEFORE, at first sight, one may contend that they are converses, so there is no need to postulate them both as primes. But as the authors of the NSM approach state (Wierzbicka 1996: 57; Goddard 1998: 326; Goddard and Wierzbicka 2002: 15-16), there is a difference in perspective, a different configuration of trajector and landmark, if we were to use Langackerean terms (see Langacker 2009). 'Y happened after $\mathrm{X}$ ' cannot be paraphrased without loss of meaning as 'X happened before $\mathrm{Y}^{\prime}$; it is a matter of a different viewpoint. Reducing the two to something as 'temporal sequence' also seems counterintuitive, because it is much easier to find terms such as AFTER and BEFORE across languages of the world, than the very abstract term of 'temporal sequence'.

In the classic NSM work, Semantics: Primes and Universals (Wierzbicka 1996), the TIME set was expanded. Four new primes were added-two duration (or time period) antonyms A LONG TIME and A SHORT TIME, accounting for the 'passage of time', a deictic Now and a 'vague' duration term FOR SOME TIME, which was posited only tentatively. As for NOw, it was earlier believed that it could be explicated as 'when I say this', but then it was discovered that the range of application of Now is much wider (Wierzbicka 1996: 100; Goddard 1998: 328). Now, being the basic deictic time marker, is used with all NSM predicates, especially the mental ones: 'now I know/feel/see ... something'. The duration primes A LONG TIME and A SHORT TIME combine not only with predicates such as DO, HAPPEN, MOVE, LIVE, but also with mental predicates FEEL and THINK: 'I felt something bad for a long time'. What is less obvious is that they both collocate well with BEFORE and AFTER, and hence can appear within temporal adjuncts, as in 'it happened a long time before' (see also Goddard and Wierzbicka 2002: 70). And they can function on their own, as can be seen from the previous examples, as 'durational adjuncts'. What is important to note though, is that the range of contexts in which they

4 WHEN can also be used in a bi-clausal construction, such as: 'when I did these things, I felt something bad' (see Wierzbicka 1996: 132). 
can occur depends on the lexical aspect of the predicate (one may say 'this someone lived for a long time', but not *'this someone died for a long time', see Goddard and Wierzbicka 2002: 71). ${ }^{5}$

The most recent TIME prime is MOMENT, added in 2002 (Goddard 2002: 301). This prime accounts for the immediacy of some actions and reactions, and expresses the idea of suddenness (Goddard 2018: 75). It is, so to say, punctual, it is time with almost no duration: such as in it happened a moment before'. And, as we can see from this example, MOMENT, just as the duration primes, can be used with BEFORE and AFTER. ${ }^{6}$

Interestingly, in many languages of the world (e.g. Polish, Hopi, Kayardild) the exponents of BEFORE and AFTER are polysemous and mean also 'in front of' or 'going ahead of' and 'behind' or 'following', respectively (see also Goddard 2001: 46; Goddard and Wierzbicka 2002: 68). It is worth noting here that there is a strict correspondence between the NSM primes of TIME and SPACE. As Goddard and Wierzbicka put it:

There is a certain degree of parallelism in the inventory of proposed primes of time and space ... we can see that both domains have a 'categorical' or substantive-like element [correspondingly WHEN - TIME and WHERE - PLACE], that both have a deictic element [NOW and HERE], that both have a pair of relational antonyms [AFTER, BEFORE and ABOVE, BELOW], and also a pair of 'scalar' antonyms [A LONG TIME, A SHORT TIME and FAR, NEAR]. In view of these facts, it is not surprising that there are numerous parallels in the combinatorial characteristics of temporal expressions and spatial expressions. (2002: 66)

\section{Emotions and TIME}

As Averill (1994: 384, 385) points out, our emotional experience 'is not static, but [it] extends in time' and 'emotions differ greatly in their temporal course'. Many researchers view emotions as scripts, narratives or scenarios

5 One may think that these durational elements, A LONG TIME and A SHORT TIME, are based on the prime TIME, and hence are too complicated to be considered primitive. We must remember though that in many languages their exponents are simple, unanalysable words-e.g. in Polish, DŁUGO and KRÓтко- that have nothing to do with the lexical exponent of the prime wHEN $\sim$ TIME (see Goddard and Wierzbicka 2002: 67).

6 The introduction of the prime MOMENT is also related to the fact that the combination 'a very short time' is not available cross-linguistically (Goddard 2002: 301-03). 
(see e.g. Shweder 1994; Kövecses 1995; Apresjan and Apresjan 2000). If emotions are narratives, they extend over time, hence the importance of temporal primes in their explications.

Within the NSM framework, emotions are normally defined through a prototypical cognitive scenario (Goddard 1998: 95; Goddard 2018: 70). Usually there is someone who 'is thinking about something' that he did or about something that happened or can happen to him. As a result, this person is feeling 'something good' or 'something bad' for some time. Hence, the prototypical scenario gives us a clue how a person experiencing the given emotion may feel. These thoughts and feelings are considered a prototype of the emotion in question: 'like people often feel when they think like this'. As Páez and Vergara (1995: 415) note, the prototypical emotional scenarios are embedded in, and dependent on, culture'. That is why emotion terms are so different in every linguaculture. And they can be seen as 'a record of how earlier generations of speakers of a given language thought about their feelings' (Besemeres and Wierzbicka 2010: 20). In a sense, names of emotions are linguistic artefacts in which past experiences of a given community are crystallised. As such, they are dependent on the geographical and historical conditions that community lives in (for interesting examples, see Briggs 1971 on Inuit emotions). By analysing emotion names, we gain an insight into the history of that community. It is not surprising that in Portuguese we find a word saudade, an emotion term basic to the Portuguese identity, that relates to the centuries-long history of Portuguese colonisation of the world and to the separation of families caused by that maritime expansion.

Emotions may also differ as far as time perspective is concerned. Some of them relate to past experiences, others are about things happening now and 'have distinctly present perspective' (Goddard 1998: 92 on happy and joy; see also Goddard 2018: 77 on pleased and contented). Emotions differ in their intensity as well. 'Some emotions are more like sneezes, others more like crimes', as Dixon (2003: 246) notes, wittily. And, as Clore (1994: 391) suggests, emotional intensity is a function of amplitude multiplied by duration, rather than merely amplitude. So there must be some correlation between the duration and the intensity of an emotion. Expressions like for some time and in one moment help us to distinguish between prolonged feelings (e.g. saudade) and momentary ones (e.g. surprise; see also Goddard 2018: 71). 
According to some psychologists (Davidson 1994: 51; Ekman 1994: 16), emotions do not last longer than a few minutes, and if they do, they are dysfunctional (Ekman and Davidson 1994: 419; see also Ekman 1994: 16: ' $\mathrm{h}]$ ere is not the place to argue about just how long an emotion typically lasts, but certainly it is not hours or days, but more in the realm of minutes and seconds'). Watson and Clark (1994: 90) claim along similar lines that 'emotions ... are typically quite short-lived in their full form, lasting only a few seconds or perhaps minutes'. Ekman (1994: 56) goes even further, stating that the emotional state that lasts several weeks should be classified as an affective disorder. As I will try to demonstrate later, this is a very Anglocentric point of view. ${ }^{7}$ In many cultures of the world, people are used to feelings that go on for hours, or even days, and consider long-lasting and intense emotional states as a sign of mental health, not an affective disorder (see e.g. Wierzbicka 1995: 22 on how absence of emotions is perceived as an indicator of 'a deadening of a person's dusa ('heart/soul')' in Russian culture).

There is one more question we should touch upon in speaking of the relations between emotions and time. Time perception is a very subjective phenomenon, there is no unique sense of time, but there are multiple experiences of time. And, most importantly, our judgement of time depends on how we feel. When we are happy, 'time flies' ${ }^{8}$ On the contrary, when we are in deep sorrow, time may almost stop (see DroitVallet and Gil 2009: 1947, on how sadness induces a general slowing down). As Geoffard and Luchini (2010: 271) say, 'time is not exogenous to the individual, it is elastic, and this will be influenced by the emotion the person experiences'.

As we can see, investigating the relations between time and emotions is a fascinating field of study, and there certainly is a 'critical need for research on the temporal dynamics of emotional processing' (Ekman and Davidson 1994: 419). Exploring the topic in more depth is beyond the scope of the present chapter though, so let us proceed to see how four emotion concepts referring to 'longing' differ in their time perspective.

$7 \quad$ As one of the anonymous reviewers of this chapter rightly noticed, it may be more a question of what English-speaking psychologists and not ordinary speakers of English have in mind when they talk about emotions.

8 At the same time, when we are happy, we often feel we have plenty of time, even though it passes by quickly; in fact, research shows that experiencing awe leads to expanding one's perceptions of time availability (see Rudd et al. 2012). 


\section{Portuguese saudade}

Saudade is a key emotion term in Portuguese, usually translated into English as longing, missing, homesickness or nostalgia. Its uniqueness resides in the fact that for a long time the Portuguese have seen it as a national identity marker. It is said to have emerged during the times of Great Portuguese Discoveries (Epoca dos Descobrimentos), when many left their families and departed to the unknown. Those left behind, suffering from the absence of their loved ones and longing for their return, thought of them with a mixture of melancholy and pride (see Bułat Silva 2012).

The Great Dictionary of the Portuguese Language (Machado 1981: 13) states that saudade is 'a word that probably doesn't have equivalents in other languages, and that expresses a lot of feelings, especially melancholy, caused by recalling something good that one was deprived of'. 'In the Dictionary of Contemporary Portuguese Language (Casteleiro 2001), saudade is defined as 'a memory of something that was pleasant but is distant in terms of time or space. ${ }^{10}$ In my opinion, it refers more to the domain of TIME than to the domain of SPACE, and not simply to distance in TIME, but rather, I believe, it is the PAST that constitutes the prototypical object of saudade (Bułat Silva 2012: 207). One may say that saudade is a feeling about times gone by. But, interestingly enough, it can also refer to the future (one may have saudades do futuro, 'saudades of the future'). It is typically an overwhelming and long-lasting feeling. The element of 'thinking', recalling the past, is inherent to its meaning (saudades in plural can also mean 'memories', see Casteleiro 2001). As I have written earlier (Bułat Silva 2012), equally important is the positive evaluation it has in the Portuguese culture-' não ha nada mais triste que a saudade de saudade', 'there's nothing sadder than saudade of saudade' (Barreto 1959: 22). When we have a look at the verbs that collocate most frequently with saudade, the impression of its intensity is even stronger. One may morrer de saudade, 'die of saudade', and one can also matar saudade, 'kill saudade' (by seeing people he missed so badly), just as one can morrer de fome, 'die out of hunger', and matar a fome, 'kill the hunger' (by eating something). These parallels in metaphorical expressions show that psychological reaction to saudade may be similar to the body's reaction to hunger (see Apresjan and

9 Vocábulo considerado sem equivalente noutras línguas e que exprime multiplicidade de sentimentos, sobretudo a melancolia causada pela lembrança do bem do qual se está privado.

10 Recordação de alguma coisa que foi agradável mas que está distante no tempo ou no espaço. 
Apresjan 2000: 205: 'emotion is hardly ever expressed directly, but always compared to something'). And just as hunger, saudade is perceived as an emotion that doesn't leave much space for other thoughts or feelings.

Now let us try to summarise what have just been said about saudade, using the simple and cross-translatable words of NSM:

\section{[A] Tenho saudades de ...}

a. I think like this:

b. $\quad$ some time before something very good was happening to me for some time

c. I felt something very good because of this

d. it is not happening now

e. I very much want this to be happening now

f. I know it can't happen anymore

g. this is bad

h. I can't not think about it

i. at the same time I think like this:

j. $\quad$ some time before something very good was happening to me for some time

k. I felt something very good because of this

I. I can think about it now

m. this is good

n. when I think like this, I feel something like people feel at many times when they think like this for a long time

o. it is good if someone can feel something like this

Source: Bułat Silva (2012: 207).

The explication in [A] starts with 'I think' to capture the element of nostalgic thoughts that constitute the base for the feeling (a). Saudade is paradoxical -its cognitive scenario is that of having ambiguous thoughts about the past. Therefore someone thinks: 'some time before something very good was happening to me for some time' (b) and because of that 'I felt something very good' (c). But it is not happening anymore (d), even though this person would very much like it to be happening (e). It is a very acute feeling. And that fact is stressed by the use of the deictic 
now twice. First, in line (d) when the person experiences some kind of loss or emptiness and then, in line (e) when this somebody desires to revive the past. There is also some kind of Portuguese fatalistic resignation towards the future embedded in (f), 'I know it can't happen anymore', and a negative appraisal, 'this is bad', in (g). The pervasiveness of saudade is captured in line (h): 'I can't not think about it'. At the same time the person appreciates having good past experiences $(\mathrm{j})$ and feelings $(\mathrm{k})$. Those memories are a reason for a positive appraisal now $(\mathrm{l}, \mathrm{m})$. All this makes this person feel 'something like people often feel when they think like this for a long time'. In that component the long-lasting quality of saudade is substantiated. The very last component (o) shows that saudade is positively valued in the Portuguese culture.

\section{Saudade and other emotions of longing}

\subsection{Saudade vs tęsknota}

Patrick Farell, in his article 'Portuguese saudade and other emotions of absence and longing' (2006: 336), suggested that of all the languages known to him, the closest counterpart of Portuguese saudade is the Polish word tęsknota. I must disagree with him though. In spite of being a very salient Polish emotion word, tęsknota has a different focus than that of saudade. Having a quick look at the explications of the two ([A] and $[\mathrm{B}]$ respectively), we may easily see that tęsknota is much more SPACE-oriented. As Wierzbicka (1992: 125) argues, it has ojczyzna, 'patria', as its prototypical stimulus. Tesknota is said to have gained its status of a Polish key concept during the so-called Great Emigration in the nineteenth century. In 1795, Polish lands were divided and seized (for the third time) by three neighbouring powers, Austria, Prussia and Russia, and that caused a great exile of the political, literary and artistic elite. One of the dominant themes (and the driving force) of their work was tesknota, the pain of being away from their homeland (cf. Goddard and Wierzbicka 2008: 205-07). Today tęsknota is often felt towards a person, as in the explication quoted below, but even then it implies absence or separation in SPACE rather than in TIME. One feels something very bad, because one thinks about someone who is very far from the place that person is. In NSM simple terms, the verb tęsknić, 'to have tęsknota towards someone' is explicated as follows: 


\section{[B] ktoś (X) tęskni do kogoś (Y)}
a. this someone $(X)$ thinks about someone else $(Y)$
b. when $X$ thinks about $Y, X$ feels something very bad
c. like someone can feel when they think like this about someone:
d. this someone is very far from the place where I am now
e. because of this I can't be with this someone now
f. when I was with this someone before, I felt something good
g. I want to be with this someone now

Source: Goddard and Wierzbicka (2008: 206). ${ }^{11}$

As we can see, there are less temporal primes featuring in the above definition, and it is due to the fact that prototypical stimulus of tęsknota is distance in SPACE, not in TIME ${ }^{12}$ (although tęsknota is also a very acute feeling: the deictic now is used three times in its explication). It is important to distinguish two syntactic frames of the verb tęsknić: tęsknić do and tęsknić $z a{ }^{13}$ According to Grzegorczykowa (1999), the former is future-oriented, while the latter is past-oriented and somewhat fatalistic, but both refer to cierpienie wywotane roztąka z bliskimi ludżmi (miejscami), 'pain caused by separation from a beloved person (or place)' (Grzegorczykowa 1999: 203). Saudade, as it was said before, is TIME-oriented, it is about something good one had in the past, and it can also refer to something good that can happen in the future, but it most likely won't—as in saudades do futuro, 'nostalgia of the future', or saudades do que ainda nâo aconteceu, 'saudades of something that hasn't come to being yet'.

\subsection{Saudade vs morriña}

Interestingly, saudade doesn't have a cognate in Spanish. Maybe the closest Spanish counterpart of saudade would be añoranza, 'longing' (from añorar, 'recordar con pena la ausencia, privación o pérdida de alguien

11 For the explication of tęsknić do miejsca, 'to feel tęsknota towards a place', see Goddard (2018: 80).

12 One of the anonymous reviewers of this chapter suggested that the prototypical stimulus of tęsknota is nieobecność 'absence' rather spatial distance. I think being separated from one another implies distance in SPACE, whatever the reason for that separation is (emigration, work travel, end of the relationship).

13 Do is roughly 'to' in English, and $z a$ could be translated as 'for'. Actually, there is one more syntactic frame tęsknić po, roughly 'after', but as it is an archaic expression (which can be found e.g. in Adam Mickiewicz's works), it lies beyond the scope of the present chapter. 
o algo muy querido' 'to recall with sorrow the absence or loss of someone or something we love', see RAE 2014). Often saudade is translated into Spanish as nostalgia. And there is one more Spanish word of Galician origin that can be considered equivalent to saudade, that is morrina, defined by the Dictionary of Spanish Language as 'tristeza o melancolia, especialmente la nostalgia de la tierra natal', 'sadness or melancholy, especially nostalgia for one's homeland' (RAE 2014). Morriña is said to emerge as a result of the emigration of people from rural Spain to Argentina in the second half of the nineteenth century, so it is strongly SPACE-oriented, very much like Polish tęsknota (Goddard and Wierzbicka 2008). Unlike tęsknota though, morriña has also a very clear reference to the past, specifically to the times of one's childhood. As the explication in [C] says:

\section{[C] morriña}

a. someone $(X)$ thinks about this place $(Y)$

b. when $X$ thinks about place $Y, X$ feels something bad

c. like someone can feel when they think like this about a place:

d. 'I am like a part of this small place

e. I did many things with people there when I was a child [m]

f. I felt many good things at many times when I was there

g. I want to be in this place now

h. I know that I can't be in this place now because it is far from here'

Source: Goddard and Wierzbicka (2008: 12).

Morriña has one's tierra natal, 'homeland' or 'land of one's birth' (Heimat in German), as a prototypical target (small place in line (d)). One is far away from that place and cannot easily come back $(\mathrm{g}-\mathrm{h})$. Morriña is accompanied by memories of one's childhood (e) and of happiness resulting from being a part of a community and sharing joys and troubles with it (f). ${ }^{14}$ Morriña is similar to saudade in that memory-based element. Comparing to saudade though, it is more focused on SPACE, but they both share the component of a desire that cannot be fulfilled (line (f) in [A] and $(\mathrm{h})$ in $[\mathrm{C}])$ that Polish tęsknota lacks.

14 In the most recent explication of morriñ in Goddard (2018: 83), there is a stronger reference to community. Line (d) in [C] is rewritten as 'some people are like a part of this small place, I am one of these people'. 


\subsection{Saudade and chou}

Having compared saudade with two 'nostalgic emotions' relating to SPACE, tesknota and morriña, let us look now at a Chinese nostalgia, chou, that is, just like saudade, TIME-oriented. Unlike saudade though, it refers more to the present than to the past. Chou is a very salient Chinese emotion usually translated into English as 'sadness', 'homesickness' or 'profound melancholy' (Ye 2001: 378-91). Comparing to other SADNESS words in Chinese, bei (roughly 'sorrow', 'sadness') and ai ('sorrow', 'grief'), chou is strikingly ego-oriented. When describing chou, Ye (2001: 379) gives the following glosses 'sadness at leaving a friend; the loneliness of setting out on a journey in a tiny boat on the vast sea; ... emptiness ...; yearning ...; depression and dissatisfaction caused by the inability to achieve what one yearns for; confusion in not knowing what to do ...; the inability to put an end to one's chou'.

\section{[D] chou}
a. $\quad X$ felt something because $X$ thought something
b. sometimes a person thinks:
c. 'something very bad is happening to me
d. before this, I did not think this would happen
e. I don't want things like this to happen to me
f. because of this, I want to do something if I can
g. I don't know what to do
h. I cannot not think about this all the time'
i. when this person thinks this, this person feels something bad for a long time
j. $\quad X$ felt something like this
k. because $X$ thought something like this

Source: Ye (2001: 383).

When we look at the NSM definition in [D] proposed by Ye (2001:383), we may see that chou is experienced in difficult, stressful and unpredictable situations ('something very bad is happening to me/before this I did not think this would happen', (c)-(f)). The experiencer is confused and doesn't know what to do $(\mathrm{g})$. The feeling of chou is overwhelming and persistent 
and this person cannot stop thinking about bad things that are happening to them (h). The component (i) conveys the long duration of chou, 'this person feels something bad for a long time'. If we compare saudade to chou, we can see immediately that both of them are long-lasting emotions. ${ }^{15}$ They are both overwhelming, pervasive feelings - one cannot stop thinking about what is happening. We may notice that in the definition of chou this pervasiveness is even more intense - it is stressed by the expression all the time in line (h). While saudade is a bipolar, paradoxical feeling based on both positive and negative thoughts towards the past, chou is negative and refers in a more straightforward manner to 'feeling something bad'.

\section{Concluding remarks}

The present comparison of 'nostalgia' terms in Portuguese, Polish, Spanish and Chinese seems to confirm the fact already pointed out by Geertz (1973: 81) that emotions are cultural artefacts. We cannot translate emotion names easily, because of rich semantic content such words possess. Nostalgia-like emotion terms have a special relation to the past, and a great deal of what happened to a given community can be seen when we unpack their meaning. Saudade recalls the epoch of Great Portuguese Discoveries (Época dos Descobrimentos), when the Portuguese were one of the most powerful nations in the world. Tesknota speaks about the three partitions of Poland, and the great pain of those who had to leave the country. Morriña brings into one's mind millions of gallegos who emigrated to Argentina and Chile in the nineteenth century. As Apresjan and Apresjan (2000: 203) note, 'language contains the experience of millennia of psychological and cultural introspection and its data are every bit as reliable as those provided by experimental research'. By studying semantics we may learn a lot about history.

Emotions are not punctual, but they are more like stories or scenarios that extend in time. And, as we have seen, in some cultures emotions that we refer to as 'longing' simply last longer than in others. Saudade and chou seem to be more pervasive, more overwhelming emotions than morrina and tesknota. Why is that so? My hypothesis would be that what makes saudade such a long-lasting feeling is the CHANGE between all the good

15 Note that also toska, a Russian word for 'longing' or 'ennui' shares the same component of lasting for hours or even days, see Wierzbicka (1992). 
memories of the past and the present feelings of emptiness and absence that are experienced by the subject. It is this constant change between feeling something good and feeling something bad that allows saudade to persist for such long periods of time. It does not focus on something bad happening to a person, but rather submerges in the past and then comes back to the present. And it is that swinging motion between good and bad feelings that allows the TIME pendulum to go on for so long. Further studies on chou are needed in order to explain its long-lasting quality.

We can also note that the emotions we feel change our subjective sense of time. When we feel nostalgic, or sad, time is most likely to slow down and we may experience it differently. Portuguese identity is said to be based on experiencing saudade - maybe this is why Portuguese people are perceived as passive by their more energetic Spanish neighbours?

Summing up, we may say that emotions relate to time in three different ways - as cultural artefacts of the past (1), as scenarios taking place within a specific amount of time (2) and as psychological processes that can change our subjective sense of time, adjusting our internal clock to the kind of emotion we feel (3).

\section{Acknowledgements}

The author of this article would like to thank two anonymous reviewers whose insightful comments helped improve the final draft.

\section{References}

Apresjan, Jurij and Valentina Apresjan (2000). Metaphor in the semantic representation of emotions. Systematic Lexicography: 203-14.

Averill, James R. (1994). I feel, therefore I am-I think. In Paul Ekman and Richard J. Davidson (eds), The Nature of Emotions: Fundamental Questions. Oxford: Oxford University Press, 379-85.

Barreto, Mascarenhas (1959). Fado: A canção portuguesa. Lisboa.

Besemeres, Mary and Anna Wierzbicka (2010). Emotion terms as a window on culture, social psychology and subjective experience. In S.V. Ionov (ed.), Jazyk i emociia. Volgograd: Volgogradskoe Nauchnoe Izdatel'stvo, 14-32. 
Briggs, Jean L. (1971). Never in Anger. Harvard: Harvard University Press.

Bułat Silva, Zuzanna (2012). Saudade - A key Portuguese emotion. Emotion Review 4 (2): 203-11. doi.org/10.1177/1754073911430727.

Casteleiro, João Malaca (2001). Dicionário da Lingua Portuguesa Contemporânea [Dictionary of the Contemporary Portuguese Language]. Lisboa: Verbo.

Clore, Gerald L. (1994). Why emotions vary in intensity. In Paul Ekman and Richard J. Davidson, The Nature of Emotions: Fundamental Questions. Oxford: Oxford University Press, 386-93.

Davidson, Richard J. (1994). On emotion, mood and related affective constructs. In Paul Ekman and Richard J. Davidson (eds), The Nature of Emotions: Fundamental Questions. Oxford: Oxford University Press, 51-55.

Dixon, Thomas (2003). From Passions to Emotions: The Creation of a Secular Psychological Category. Cambridge: Cambridge University Press.

Droit-Volet, Slyvie and Sandrine Gil (2009). The time-emotion paradox. Philosophical Transactions of the Royal Society 364: 1943-53. doi.org/10.1098/ rstb.2009.0013.

Ekman, Paul (1994). All emotions are basic. In Paul Ekman and Richard J. Davidson (eds), The Nature of Emotions: Fundamental Questions. Oxford: Oxford University Press, 15-19.

Ekman, Paul and Richard J. Davidson (eds) (1994). The Nature of Emotions: Fundamental Questions. Oxford: Oxford University Press.

Farrell, Patrick (2006). Portuguese saudade and other emotions of absence and longing. In Bert Peeters (ed.), Semantic Primes and Universal Grammar: Empirical Evidence from the Romance Languages. Amsterdam: John Benjamins, 235-58. doi.org/10.1075/slcs.81.16far.

Geertz, Clifford (1973). The Interpretation of Cultures. New York: Basic Books.

Geoffard, Pierre Yves and Stéphane Luchini (2010). Changing time and emotions. Philosophical Transactions of the Royal Society 365: 271-80. doi.org/10.1098/ rstb.2009.0178.

Goddard, Cliff (1998). Semantic Analysis: A Practical Introduction. Oxford: Oxford University Press.

Goddard, Cliff (2001). Lexico-semantic universals: A critical overview. Linguistic Typology 5: 1-65. doi.org/10.1515/lity.5.1.1. 
Goddard, Cliff (2002). The ongoing development of the NSM research program. In Cliff Goddard and Anna Wierzbicka (eds), Meaning and Universal Grammar: Theory and Empirical Findings (Vol. 2). Amsterdam: John Benjamins, 301-21. doi.org/10.1075/slcs.61.11god.

Goddard, Cliff (2018). Ten Lectures on Natural Semantic Metalanguage: Exploring Language, Thought and Culture Using Simple, Translatable Words. Leiden: Brill.

Goddard, Cliff and Anna Wierzbicka (eds) (1994). Semantic and Lexical Universals: Theory and Empirical Findings. Amsterdam: John Benjamins.

Goddard, Cliff and Anna Wierzbicka (eds) (2002). Meaning and Universal Grammar: Theory and Empirical Findings (2 vol.). Amsterdam: John Benjamins.

Goddard, Cliff and Anna Wierzbicka (2008). Universal human concepts as a basis for contrastive linguistic semantics. In María de los Ángeles GómezGonzáles, J. Lachlan Mackenzie, Anne-Marie Simon-Vandenbergen and Elsa Gonzáles Álvarez (eds), Current Trends in Contrastive Linguistics: Functional and Cognitive Perspectives. Amsterdam: John Benjamins, 205-26. doi.org/10.1075/ sfsl.60.13god.

Grzegorczykowa, Renata (1999). Z badań nad porównawczą semantyką leksykalną: nazwy 'tęsknoty' w różnych językach [From the research on comparative lexical semantics: names for 'longing' in different languages]. In Zbigniew Greń and Violetta Koseska-Toszewa (eds), Semantyka a konfrontacja jezykowa [Semantics and Linguistic Confrontation]. Warszawa: 199-204.

Kövecses, Zoltan (1995). Language and emotion concepts. In James A. Russell, José-Miguel Fernández-Dols, Antony S.R. Manstead and J.C. Wellenkamp (eds), Everyday Conceptions of Emotion: An Introduction to the Psychology, Anthropology, and Linguistics of Emotion. Dordrecht: Kluwer Academic Publishers, 3-15. doi.org/10.1007/978-94-015-8484-5.

Langacker, Ronald W. (2009). Gramatyka kognitywna. Wprowadzenie. Kraków: Universitas. [Original title: Langacker, Ronald W. (2008). Cognitive Grammar: A Basic Introduction. Oxford: Oxford University Press.]

Machado José Pedro (ed.) (1981). Grande Dicionário da Lingua Portuguesa [Great Dictionary of the Portuguese Language]. Lisboa: Amigos do Livro Editores.

Páez, D. and A.I. Vergara (1995). Culture differences in emotional knowledge. In James A. Russell, José-Miguel Fernández-Dols, Antony S.R. Manstead and J.C. Wellenkamp (eds), Everyday Conceptions of Emotion: An Introduction to the Psychology, Anthropology, and Linguistics of Emotion. Dordrecht: Kluwer Academic Publishers, 415-34. doi.org/10.1007/978-94-015-8484-5_24. 
RAE (Real Academia Española) (2014). Diccionario de la Lengua Española [Dictionary of the Spanish Language] (23rd edn) [online]. Available at: dle.rae.es.

Rudd, Melanie, Kathleen D. Vohs and Jennifer Aaker (2012). Awe expands people's perception of time, alters decision making, and enhances well-being. PsychologicalScience 23 (10): 1130-36. doi.org/10.1177/0956797612438731.

Shweder, Richard (1994). 'You're not sick, you're just in love': Emotion as an interpretive system. In Paul Ekman and Richard J. Davidson, The Nature of Emotions: Fundamental Questions. Oxford: Oxford University Press, 32-44.

Watson, David and Lee Anna Clark (1994). Emotions, moods, traits, and temperaments: Conceptual distinctions and empirical findings. In Paul Ekman and Richard J. Davidson, The Nature of Emotions: Fundamental Questions. Oxford: Oxford University Press, 89-93.

Wierzbicka, Anna (1972). Semantic Primitives. Frankfurt: Athenäum.

Wierzbicka, Anna (1992). Semantics, Culture, and Cognition: Universal Human Concepts in Culture-Specific Configurations. New York: Oxford University Press.

Wierzbicka, Anna (1995). Everyday conceptions of emotion: A semantic perspective. In James A. Russell, José-Miguel Fernández-Dols, Antony S.R. Manstead and J.C. Wellenkamp (eds), Everyday Conceptions of Emotion: An Introduction to the Psychology, Anthropology, and Linguistics of Emotion. Dordrecht: Kluwer Academic Publishers, 17-47. doi.org/10.1007/978-94015-8484-5_2.

Wierzbicka, Anna (1996). Semantics: Primes and Universals. Oxford: Oxford University Press.

Wierzbicka, Anna (2009). Language and metalanguage: Key issues in emotion research. Emotion Review 1 (1): 3-14. doi.org/10.1177/1754073908097175.

Ye, Zhengdao (2001). An inquiry into 'sadness' in Chinese. In Jean Harkins and Anna Wierzbicka (eds), Emotions in Crosslinguistic Perspective, Berlin/New York: Mouton de Gruyter, 359-404. 
This text is taken from Meaning, Life and Culture: In conversation with Anna Wierzbicka, edited by Helen Bromhead and Zhengdao Ye, published 2020 by ANU Press, The Australian National University,

Canberra, Australia.

doi.org/10.22459/MLC.2020.11 